\title{
Effect of Human Immunodeficiency Virus Infection on Hepatitis C Virus Infection in Hemophiliacs
}

\author{
M.G. GHANY, MD, C. LEISSINGER, MD, R. LAGIER, R. SANCHEZ-PESCADOR, PhD, and \\ A.S.F. LOK, MD
}

\begin{abstract}
Chronic liver disease due to hepatitis $\mathrm{C}$ virus (HCV) infection is a major problem in hemophiliacs. Recent reports suggested that hemophiliacs coinfected with hepatitis $\mathrm{C}$ virus and human immunodeficiency virus (HIV) have an increased incidence of liver failure but the mechanism of accelerated liver injury is not clear. We tested plasma from 100 hemophiliacs for anti-HCV by second generation ELISA, anti-HIV by EIA, and HCV RNA and HIV RNA by branched DNA and polymerase chain reaction assays to determine if hemophiliacs coinfected with HCV and HIV have higher HCV RNA levels and more active liver disease. Seventy-nine $(79 \%)$ patients were anti-HCV positive, of whom $85 \%$ were HCV RNA positive. None of the anti-HCV-negative patients had detectable HCV RNA in plasma. Forty-two $(42 \%)$ patients were anti-HIV positive, of whom $47 \%$ had detectable HIV RNA. All the anti-HIV-positive patients were also anti-HCV positive. The prevalence of both anti-HCV and anti-HIV increased significantly with age. There was no difference in HCV RNA levels between anti-HIV-positive and anti-HIV-negative patients (mean: $21 \pm 4$ vs 18 $\pm 5 \mathrm{Meq} / \mathrm{ml}$ ), although HCV RNA levels were significantly higher in anti-HIV-positive patients with CD4 counts $<200 / \mathrm{mm}^{3}(P=0.008)$. There was an inverse correlation between HCV RNA levels and CD4 counts but no correlation was found between HCV RNA and serum aminotransferase levels. We found a high prevalence of HCV and HIV coinfection in our hemophiliacs. Hepatitis $C$ virus replication appears to be increased in patients with severe immunodeficiency secondary to progressive HIV infection. However, there was no correlation between HCV RNA and serum ALT level, suggesting that HCV is not directly cytopathic.
\end{abstract}

KEY WORDS: hepatitis C virus; hepatitis C virus RNA; human immunodeficiency virus; chronic liver disease; hemophilia.

More than $50 \%$ of multitransfused hemophiliacs who received untreated clotting factors have chronic or intermittent abnormalities in liver biochemistries (1-

\footnotetext{
Manuscript received July 9, 1995; revised manuscript received February 23, 1996; accepted March 8, 1996.

From the Section of Gastroenterology and Hepatology, and Hematology and Oncology, Department of Medicine, Tulane University School of Medicine, New Orleans, Louisiana; and Chiron Corporation, Emeryville, California.

Address for reprint requests: Dr. A.S.F. Lok, Division of Gastroenterology, University of Michigan Medical Center, 3912 Taubman Center, Box 0362, Ann Arbor, Michigan 48109.
}

$3)$, and up to $15 \%$ have established cirrhosis on liver biopsies (3-6). The predominant cause of chronic liver disease in hemophiliacs has now been shown to be due to hepatitis $\mathrm{C}$ virus (HCV) (7-11). It has also been shown that multitransfused hemophiliacs who received clotting factors prior to 1985 have a high prevalence of human immunodeficiency virus (HIV) infection (12). Thus, many hemophiliacs are dually infected with HCV and HIV.

Three studies suggested that patients with concur- 
rent $\mathrm{HCV}$ and HIV infection have an increased incidence of liver failure compared to patients infected with HCV alone (13-15). Martin et al reported that all three patients with concurrent HIV infection and non-A, non-B (NANB) hepatitis developed hepatic decompensation within three years of overt hepatitis in contrast to $8(8.5 \%)$ of 94 patients who had NANB hepatitis alone (13). Eyster et al found that $8(9 \%)$ of 91 hemophiliacs with concurrent HCV and HIV infection developed liver failure compared to none of 58 hemophiliacs with $\mathrm{HCV}$ alone (age adjusted $P=$ 0.034 , relative risk $=3.2$ ) (14). Telfer et al reported that the relative risk of developing liver failure was 21 in hemophiliacs coinfected with HCV and HIV compared to hemophiliacs with HCV infection alone (15). However, other factors such as age, alcohol, medications, and concurrent opportunistic infections secondary to HIV infection may have contributed to the liver failure in some of these patients. Thus, the mechanism(s) by which HIV infection accelerates the progression of HCV related liver disease is unclear.

Several studies have now shown that patients with concurrent HCV and HIV infection have higher serum HCV RNA levels, suggesting that concurrent HIV infection increases HCV replication $(16,17)$. Eyster et al found a significant increase in HCV RNA levels in anti-HCV-positive hemophiliacs who developed superinfection with HIV and an eightfold faster rate of increase in HCV RNA levels during follow-up compared to those who remained HIV negative (17). They also found a negative correlation between $\mathrm{HCV}$ RNA levels and CD4 counts and a positive correlation between serum HCV RNA and aspartate aminotransferase (AST) levels, suggesting that acceleration of liver disease in hemophiliacs with concurrent $\mathrm{HCV}$ and HIV infection may be due to enhanced HCV replication secondary to progressive immunodeficiency. However, the correlation between serum HCV RNA levels and activity of liver disease remains controversial (16-21). This is in part related to the difficulty in accurate quantitation of serum HCV RNA levels using polymerase chain reaction (PCR) assays, and the lack of longitudinal studies with adequate time points.

This study was conducted to determine: (1) the prevalence of HCV and HIV infection in a cohort of hemophiliacs, (2) if HCV RNA levels are higher in hemophiliacs with concurrent HIV infection and if there is an inverse correlation with CD4 counts, (3) if liver disease is more active in hemophiliacs with concurrent HIV infection, and (4) if there is a positive correlation between serum ALT and HCV RNA levels.

\section{MATERIALS AND METHODS}

Patients. A total of 99 hemophiliacs and one patient with von Willebrand's disease who were followed at the Louisiana Comprehensive Hemophilia Care Center at Tulane University School of Medicine were studied. There were 99 males and one female, with a mean age of $23.2 \pm 1.4$ years, (range 2-65 years). None of the patients were known to abuse drugs or alcohol.

Methods. Citrated plasma samples were prospectively collected between 1993 and 1994 and stored at $-70^{\circ} \mathrm{C}$ prior to testing. All patients were tested for HCV antibody (antiHCV), HIV antibody (anti-HIV), hepatitis B surface antigen (HBsAg), hepatitis $\mathrm{B}$ core antibody (anti-HBc), $\mathrm{HCV}$ RNA, and liver chemistries. HIV RNA and CD4 counts were obtained in all anti-HIV-positive patients. Anti-HCV was tested by ELISA-2 (Chiron Corporation, Emeryville, California), and quantitative HCV RNA level by the branched DNA (bDNA) assay (Chiron). All patients who had undetectable HCV RNA levels in the bDNA assay were retested for HCV RNA by qualitative reverse transcription-PCR assay as previously described (22). Anti-HIV was detected by EIA (Abbott Laboratories, North Chicago, Illinois), and all positive samples were confirmed by western blot. HIV RNA levels were quantitated by the bDNA assay (Chiron). The cutoff values for detection of HCV RNA and HIV RNA were $0.35 \times 10^{6} \mathrm{eq} / \mathrm{ml}$ and $1.0 \times 10^{4} \mathrm{eq} / \mathrm{ml}$, respectively. $\mathrm{HBsAg}$ and anti-HBc were tested by ELISA (Abbott). Liver chemistries and CD4 counts were determined by standard methods. Activity of liver disease was assessed by serum alanine aminotransferase (ALT) levels, as we think that it was not justifiable to perform liver biopsies on these patients because of the risks of bleeding and the extra costs of factor concentrates and prolonged hospital stay.

Statistics. Group comparisons were made with Student's $t$ test and chi-square test as indicated. Associations were made with Spearman's correlation; patients who were $\mathrm{HCV}$ RNA negative in the bDNA assay were excluded from the analysis. Arbitrary values were not assigned to these patients since their true HCV RNA levels may range from 0 to $0.34 \times 10^{6} \mathrm{eq} / \mathrm{ml}$.

\section{RESULTS}

Anti-HCV was detected in $79(79 \%)$ patients. Of these, $65(82 \%)$ were positive for HCV RNA by the bDNA assay. Of the 14 anti-HCV-positive patients who had HCV RNA levels below the level of detection in the bDNA assay, only $2(14 \%)$ tested positive for HCV RNA by RT-PCR. None of the anti-HCVnegative patients was found to be HCV RNA positive by the bDNA as well as the RT-PCR assays. There was a significant difference in age and mean ALT levels between anti-HCV-positive and anti-HCV- 
TABle 1. Comparison Between HCV-Positive and HCV-Negative Patients

\begin{tabular}{|c|c|c|}
\hline & $\begin{array}{c}\text { Anti-HCV+ } \\
(\mathrm{N}=79)\end{array}$ & $\begin{array}{c}A N T I-H C V- \\
(\mathrm{N}=2 I)\end{array}$ \\
\hline \multicolumn{3}{|l|}{ HBV serology } \\
\hline $\begin{array}{l}\text { HBsAg positive } \\
\text { Anti-HBc }\end{array}$ & $6(7.6)^{*}$ & $0(0)$ \\
\hline positive & $46(58.2)$ & $1(4.8)$ \\
\hline \multicolumn{3}{|l|}{ HIV serology } \\
\hline positive & $42(53.2)$ & $0(0)$ \\
\hline Elevated ALT $(N)$ & $49(62)$ & $1(4.8)$ \\
\hline \multicolumn{3}{|l|}{$\begin{array}{l}\text { ALT } \\
\quad \text { (units/liter) }\end{array}$} \\
\hline $\begin{array}{r}(\text { mean } \\
\text { Age }(y r)\end{array}$ & $66 \pm 6.2 \div$ & $20 \pm 2.5 \dagger$ \\
\hline (mean $\pm \mathrm{SEM})$ & $27 \pm 2 \ddagger$ & $9 \pm 14$ \\
\hline
\end{tabular}

* Numbers in parentheses are percentages.

$\dagger P=0.0002$.

$\ddagger P<0.0001$.

negative patients $(P<0.0001$ and $P=0.0002$, respectively) (Table 1).

Anti-HIV was detected in $42(42 \%)$ patients. Plasma samples from 38 anti-HIV-positive patients were available for HIV RNA testing. Of these, HIV RNA was detected in $18(47 \%)$. HBsAg was detected in $6(6 \%)$ and anti-HBc in $47(47 \%)$ patients. All the anti-HIV-positive and all the $\mathrm{HBsAg}$-positive patients were also anti-HCV positive.

Fifty (50\%) patients had elevated serum ALT levels, of whom only one was anti-HCV negative. This patient was an 8-year-old boy with severe factor 8 deficiency and persistently elevated ALT levels. He was $\mathrm{HBsAg}$, anti-HBc, anti-HCV, and anti-HIV negative.

The prevalence of both anti-HCV and anti-HIV increased significantly with age $(P<0.0001$ and $P=$ 0.0004 respectively, Table 2 ). The prevalence of anti$\mathrm{HCV}$ was significantly higher than that of anti-HIV for every age group. Among the children aged $\leq 10$ years, $33 \%$ were anti-HCV positive but none was anti-HIV positive. The prevalence of anti-HCV in- creased rapidly to almost $100 \%$ in patients older than 20 years, while the corresponding prevalence of antiHIV increased to $60 \%$ only.

A higher proportion of anti-HCV- and anti-HIVpositive patients were HCV RNA positive by the bDNA assay compared to the anti-HCV-positive, anti-HIV-negative patients, but the difference did not reach statistical significance. There was no significant difference in HCV RNA levels between the anti-HIVpositive and the anti-HIV-negative patients. However, as can be seen in Table 3 and Figure 1, HCV RNA levels were significantly higher in the subgroup of patients with severe immunodeficiency (CD4 counts less than $200 / \mathrm{mm}^{3}$ ). In addition, there was a significant inverse correlation between HCV RNA levels and CD4 counts (Figure 2). There was no correlation between age and HCV RNA levels (Figure 3). This was true in both anti-HIV-positive and in anti-HIV-negative patients. Of the six HBsAgpositive patients, only three were HCV RNA positive by the bDNA assay; exclusion of these three patients did not alter the results of the above analyses. Likewise, inclusion of the two anti-HCV-positive patients who were HCV RNA positive in the RT-PCR assay but negative in the bDNA assay had no impact on the above analyses.

There was no difference in the percentage of patients with elevated ALT levels as well as the mean ALT levels between the HCV-positive patients with and without concomitant HIV infection irrespective of the CD4 counts (Table 3 ).

There was no correlation between HCV RNA and ALT levels. This was true for anti-HCV- and antiHIV-positive patients as well as anti-HCV-positive, anti-HIV-negative patients (Figure 4).

Of the 38 anti-HIV-positive patients who were tested for HIV RNA, 18 (47\%) were HIV RNA positive by the bDNA assay, 17 of whom were also HCV RNA positive. There was no statistical difference in the percentage of patients who were $\mathrm{HCV}$

Table 2. Age-Specific Prevalence of HCV, HIV, and hBV Infections

\begin{tabular}{lccccc}
\hline Age $(y r)$ & $\begin{array}{c}\text { Patients } \\
(\mathrm{N})\end{array}$ & $\begin{array}{c}\text { Anti-HCV+} \\
(\mathrm{N})\end{array}$ & $\begin{array}{c}\text { Anti-HIV+ } \\
(\mathrm{N})\end{array}$ & $\begin{array}{c}H B s A g+ \\
(\mathrm{N})\end{array}$ & $\begin{array}{c}\text { Anti-HBc+ } \\
(\mathrm{N})\end{array}$ \\
\hline $0-10$ & 18 & $6(33)^{*}$ & $0(0)$ & $0(0)$ & $1(6)$ \\
$11-20$ & 30 & $22(73)$ & $11(37)$ & $3(10)$ & $11(37)$ \\
$21-30$ & 26 & $25(96)$ & $15(58)$ & $1(4)$ & $20(80)$ \\
$31-40$ & 15 & $15(100)$ & $10(67)$ & $2(13)$ & $8(53)$ \\
$>41$ & 11 & $11(100)$ & $6(55)$ & $0(0)$ & $7(64)$ \\
Total & 100 & 79 & 42 & 6 & 47 \\
& & $P<0.0001$ & $P=0.0004$ & $P=\mathrm{NS}$ & $P<0.0001$ \\
\hline
\end{tabular}

*Numbers in parentheses are percentages. 
TABle 3, COMPARISON BETWEen ANTI-HCV +/ANTI-HIV+ AND ANTI-HCV+/ANTI-HIV-PATIENTS

\begin{tabular}{|c|c|c|c|c|}
\hline & \multicolumn{4}{|c|}{$A n t i-H C V+(\mathrm{N}=79)$} \\
\hline & \multicolumn{3}{|c|}{ Anti-HIV+ } & \multirow[b]{2}{*}{ Anti-HIV- } \\
\hline & $C D_{4}<200$ & $C D_{4}>200$ & Total & \\
\hline $\begin{array}{l}\text { Anti-HCV+ } \\
(N) \\
\text { HCV RNA + }\end{array}$ & 16 & 26 & 42 & 37 \\
\hline $\begin{array}{c}\text { HCV RNA+ } \\
{[N(\%)]} \\
\text { HCV RNA }\end{array}$ & $14(88)^{*}$ & $24(92)$ & $37(88)^{*}$ & $29(78)$ \\
\hline $\begin{array}{l}\text { level } \\
\text { Meq/ml [mean }\end{array}$ & $35.6 \pm 7.7 a \dagger$ & $13.5 \pm 4.0 \mathrm{~b}$ & $21.3 \pm 4.1 \mathrm{c}$ & \\
\hline $\begin{array}{c}\text { (range)] } \\
\text { Elevated ALT }\end{array}$ & $(1.3-96.0)$ & $(0.9-90.6)$ & $(0.9-96.0)$ & $(0.4-96.0)$ \\
\hline $\begin{array}{c}{[N(\%)]} \\
\text { ALT (U/L) }\end{array}$ & $8(50)$ & $19(73)$ & $27(64)$ & $22(59)$ \\
\hline$($ mean \pm SEM $)$ & $64 \pm 13 e$ & $71 \pm 9 f$ & $68 \pm 7 \mathrm{~g}$ & $63 \pm 10 h$ \\
\hline
\end{tabular}

* Includes one patient HCV RNA positive in RT-PCR assay.

$\dagger$ a vs b, $P=0.008$; a vs d, $P=0.04 ; \mathrm{b}$ vs d, $P=\mathrm{NS}$; c vs d, $P=$ ns; e vs f, $P=\mathrm{NS}$; e vs h, $P=$ NS; f vs h, $P=$ ns; g vs h, $P=$ ns.

RNA positive or in the mean HCV RNA levels between the patients in whom HIV RNA was detected and those in whom HIV RNA was not detectable, although the numbers were too small to draw meaningful conclusions. Furthermore, there was no correlation between HCV RNA and HIV RNA levels. Surprisingly, there was no correlation between HIV RNA levels and CD4 counts, but this may again be related to the small sample size.

\section{DISCUSSION}

The prevalence of anti-HCV in our cohort of multitransfused hemophiliacs was 79\%; this is in keeping with other published data $(7-11,14,18)$. The obser-

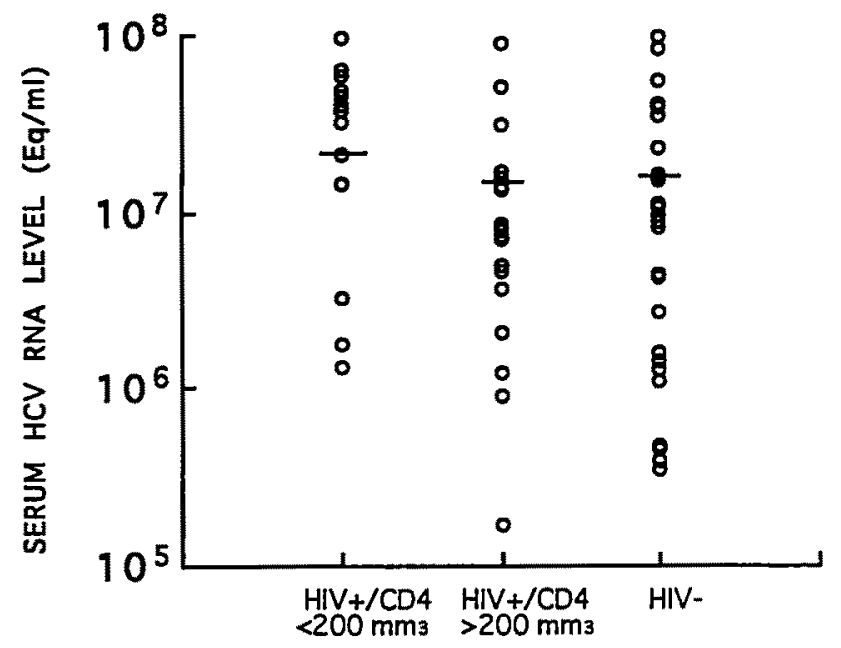

Fig 1. Serum HCV RNA levels in anti-HIV-positive and anti-HIVnegative patients. Bars denote mean HCV RNA levels. vation that all anti-HIV- and all HBsAg-positive patients were also anti-HCV positive indicates that all of these infections were most likely acquired through the same route: transfusion of clotting factor concentrates. The significant increase in prevalence of anti$\mathrm{HCV}$, anti-HIV, and anti-HBc with age reflects not only an increase in the number of units of clotting factor concentrates received in older patients but also changes in donor screening and implementation of virus-inactivating procedures in the last decade. HBsAg screening was introduced in the early $1970 \mathrm{~s}$, while anti-HIV screening began in 1985, and antiHCV screening did not take place until 1990 (23-27). Various virus-inactivation procedures have been em-

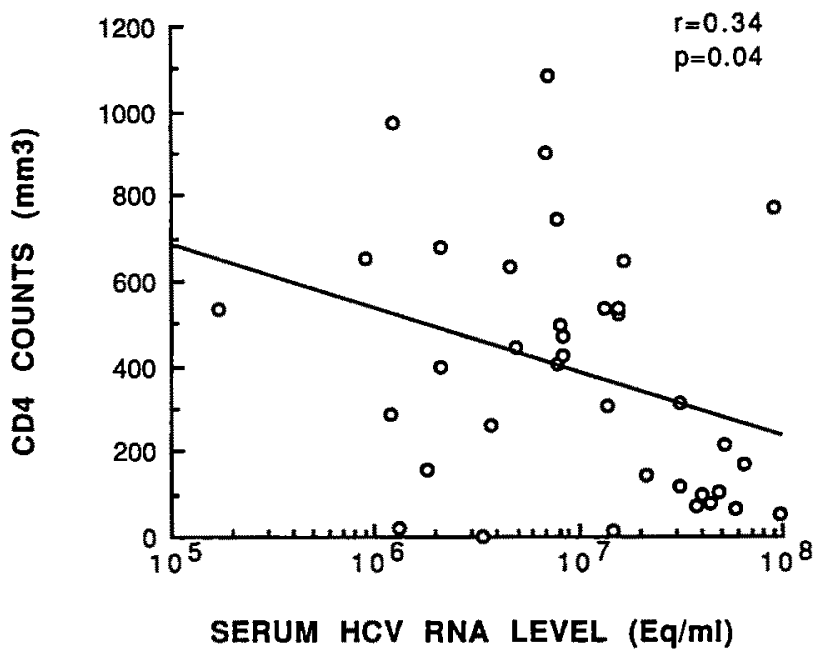

Fig 2. Correlation between serum HCV RNA levels and CD4 counts in anti-HIV-positive patients. 


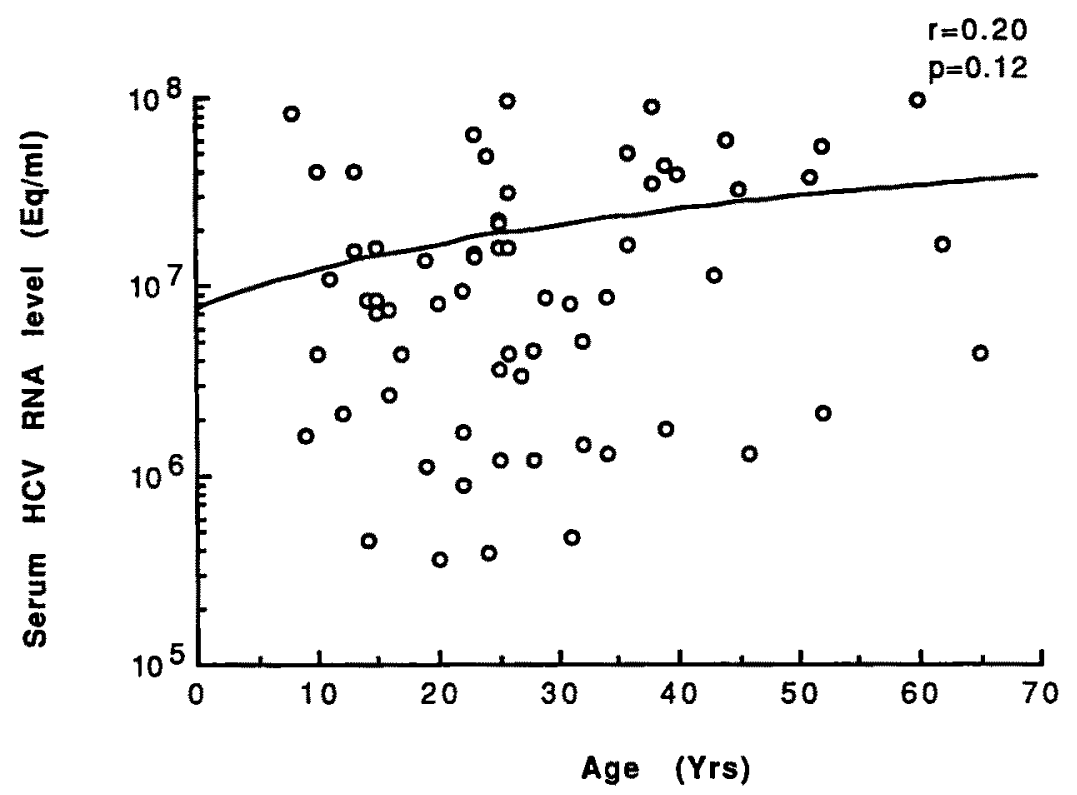

Fig 3. Correlation between age and serum HCV RNA levels in all patients.

ployed in the preparation of clotting factor concentrates in the past 10 years, but many of the earlier methods were ineffective, particularly in the elimination of non-A, non-B hepatitis (hepatitis C) $(28,29)$. Thus, effective elimination of HBV and HIV preceded that of $\mathrm{HCV}$. This accounts for the higher overall as well as age-specific prevalence of anti$\mathrm{HCV}$. The significantly lower prevalence of $\mathrm{HBsAg}$ compared to anti- $\mathrm{HBc}$ is related to the lower risk of chronicity of hepatitis B infection when acquired during childhood $(10-20 \%)$ or adult life $(<5 \%)$. In contrast, almost $100 \%$ of HIV and approximately $70 \%$ of $\mathrm{HCV}$ infections progress to chronic infection (30).

We found that most $(82 \%)$ of our anti-HCVpositive hemophiliacs were HCV RNA positive by the bDNA assay. The bDNA assay is less sensitive than PCR assays, but it has a high degree of internal consistency and is a more reliable quantitative assay (16). Only two (14\%) of our anti-HCV-positive patients who had undetectable HCV RNA levels in the bDNA assay were HCV RNA positive by RT-PCR, supporting the validity of using HCV RNA levels by the bDNA assay in our correlation analyses. Some studies have shown that HCV RNA may be present in anti-HCV-negative, multitransfused patients who are immunosuppressed (31-33). Hepatitis $C$ virus RNA was not detected in any of our anti-HCV-negative hemophiliacs, even when tested by the RT-PCR assay. This may be related to the fact that none of our anti-HCV-negative patients was immunosuppressed by concurrent HIV infection.
As a group, the anti-HIV-positive hemophiliacs had similar HCV RNA levels as the anti-HIVnegative ones, suggesting that HIV infection alone does not enhance HCV replication. This is supported by a lack of correlation between HCV RNA and HIV RNA levels, although the number of patients studied was small. In contrast, the anti-HIV-positive hemophiliacs with severe immunodeficiency as defined by CD4 counts below $200 / \mathrm{mm}^{3}$ had significantly higher HCV RNA levels compared to the anti-HIV-negative hemophiliacs as well as the anti-HIV positive ones who had CD4 counts above $200 / \mathrm{mm}^{3}$. We also found a negative correlation between HCV RNA levels and $\mathrm{CD} 4$ counts. These findings suggest that $\mathrm{HCV}$ replication is enhanced by immunodeficiency secondary to progressive HIV infection. This is in agreement with the finding of Eyster et al (17). Although the antiHIV-positive patients with CD4 counts $<200 / \mathrm{mm}^{3}$ were significantly older, the higher serum HCV RNA levels in these patients is probably unrelated to the longer duration of HCV infection, since we found no correlation between age and serum HCV RNA levels for the entire patient population or when the patients with and without HIV coinfection and those with CD4 counts above or below $200 / \mathrm{mm}^{3}$ were analyzed separately.

Fifty percent of our hemophiliacs had elevated ALT levels. Although we did not perform liver biopsies on our patients, we suspect that most of them have chronic liver disease based on histological studies of other investigators (3-6). Ninety-eight percent 

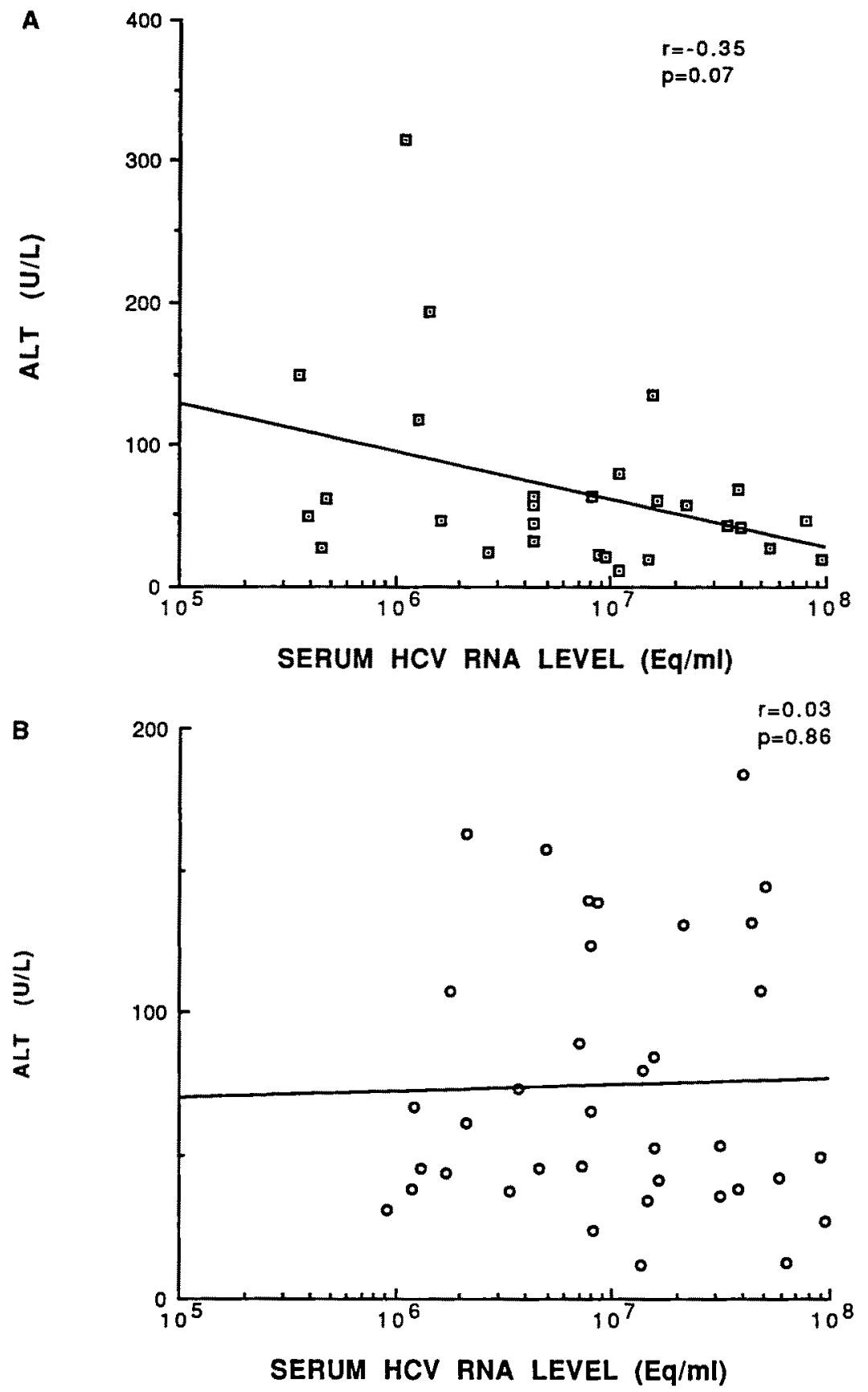

Fig 4. Correlation between serum HCV RNA and ALT levels in anti-HIV-positive (A) and anti-HIV-negative (B) patients.

of our hemophiliacs with elevated ALT levels were anti-HCV positive [including five patients (10\%) who were also $\mathrm{HBsAg}$ positive], confirming that $\mathrm{HCV}$ is the predominant cause of liver disease in hemophiliacs. Thirty-eight percent of our anti-HCV-positive hemophiliacs had normal ALT levels despite the detection of HCV RNA in $73 \%$ of them. Some of these patients may have chronic liver disease since liver biopsies of anti-HCV-positive nonhemophiliacs with normal ALT levels have shown a wide range of liver pathology from minimal changes to chronic hepatitis and cirrhosis $(19,20,34-36)$. Contrary to the findings of Eyster et al (17), we found no correlation between HCV RNA and ALT levels and no difference in ALT levels between anti-HCV-positive hemophiliacs with or without concurrent HIV infection irrespective of 
their CD4 counts. The lack of correlation between HCV RNA and ALT level or liver histology has also been reported by other investigators, suggesting that $\mathrm{HCV}$-induced liver injury may not be due to a direct cytopathic effect of the virus $(16,19,20,33,37,38)$.

Surprisingly, there was no correlation between the HIV RNA levels and CD4 counts, although there was a trend toward higher HIV RNA levels with lower $\mathrm{CD} 4$ counts. This may be related to the small number of patients.

In summary, we found a high prevalence (79\%) of anti-HCV in our cohort of hemophiliacs. More than half of these patients were also infected with HIV. There was a significant increase in the prevalence of $\mathrm{HCV}$ and HIV infection with age. HIV infection on its own did not seem to enhance HCV replication, but $\mathrm{HCV}$ replication may be increased as a result of severe immunodeficiency secondary to progressive HIV infection. We found no correlation between HCV RNA and ALT levels and no evidence of increased activity of liver disease as assessed by ALT levels in hemophiliacs with concurrent HIV infection, even in those with low $\mathrm{CD} 4$ counts and high $\mathrm{HCV}$ RNA levels.

\section{REFERENCES}

1. Cederbaum AI, Blatt PM, Levine PH: Abnormal serum transaminase levels in patients with hemophilia A. Arch Intern Med 142:481-484, 1982

2. Fletcher ML, Trowell JM, Craske J, Pavier K, Rizza CR: Non-A non-B hepatitis after transfusion of factor VIII in infrequently treated patients. BMJ 287:1754-1757, 1983

3. Preston FE, Triger DR, Underwood JCE, Bardhan G, Mitchell VE, Stewart RM, Blackburn EK: Percutaneous liver biopsy and chronic liver disease in hemophiliacs. Lancet 2:592-594, 1978

4. Aledort LM, Levine PH, Hilgartner M, Blatt P, Spero JA, Goldberg JD, Bianchi L, Desmet V, Scheuer P, Popper H, Berk PD: A study of liver biopsies and liver disease among hemophiliacs. Blood 66:367-372, 1985

5. Hay CRM, Preston FE, Triger DR, Underwood JCE: Progressive liver disease in hemophilia: An understated problem. Lancet 1:1495-1498, 1985

6. Spero JA, Lewis JH, Van Thiel DH, Hasiba U, Rabin BS: Asymptomatic structural liver disease in hemophilia. $\mathrm{N}$ Engl J Med 298:1373-1378, 1978

7. Esteban JI, Esteban R, Viladomiu C, Lopez-Talavera JC, Gonzalez A, Hernandez JM, Roget M, Vargas V, Genesca J, Buti M, Guardia J, Houghton M, Choo Q-L, Kuo G: Hepatitis $C$ virus antibodies among risk groups in Spain. Lancet 2:294297, 1989

8. Roggendorf M, Deinhardt F, Rasshofer R, Eberle J, Hopf U, Moller B, Zachoval R, Pape G, Schramm W, Rommel F: Antibodies to hepatitis $C$ virus. Lancet 2:324-325, 1989 (letter)

9. Makris M, Preston FE, Triger DR, Underwood JCE, Choo
QL, Kuo G, Houghton M: Hepatitis C antibody and chronic liver disease in hemophilia. Lancet 335:1117-1119, 1990

10. Brettler DB, Alter HJ, Dienstag JL, Forsberg AD, Levine PH: Prevalence of hepatitis $C$ virus antibody in a cohort of hemophiliac patients. Blood 76:254-256, 1990

11. Blanchette VS, Vorstman E, Shore A, Wang E, Petric M, Jett BW, Alter HJ: Hepatitis $C$ infection in children with hemophilia A and B. Blood 78:285-289, 1991

12. Goedert JJ, Kessler CM, Aledort LM, Biggar RJ, Andes WA, White II GC, Drummond JE, Vaidya K, Mann DL, Eyster E, Ragni MV, Lederman MM, Cohen AR, Bray GL, Rosenberg PS, Friedman M, Hilgartner MW, Blattner WA, Kroner B, Gail $\mathrm{MH}$ : A prospective study of human immunodeficiency virus type 1 infection and the development of AIDS in subjects with hemophilia. N Engl J Med 321:1141-1148, 1989

13. Martin P, Di Bisceglie AM, Kassianides C, Lisker-Melman M, Hoofnagle $\mathrm{JH}$ : Rapidly progressive non- $A$, non- $B$ hepatitis in patients with human immunodeficiency virus infection. Gastroenterology 97:1559-1561, 1989

14. Eyster ME, Diamondstone LS, Lien JM, Ehmann WC, Quan S, Goedert JJ, for the Multicenter Hemophilia Cohort Study: The natural history of hepatitis $\mathrm{C}$ virus (HCV) infection in multitransfused hemophiliacs: Effect of coinfection with immunodeficiency virus (HIV). J Acquir Immune Defic Synd 6:602-610, 1993

15. Telfer P, Sabin C, Devereux H, Scott F, Dusheiko G, Lee C: The progression of $\mathrm{HCV}$-associated liver disease in a cohort of haemophilic patients. Br J Haematol 87:555-561, 1994

16. Sherman KE, O'Brien J, Gutierrez AG, Harrison S, Urdea M, Neuwald P, Wilber J: Quantitative evaluation of hepatitis C virus RNA in patients with concurrent human immunodeficiency virus infections. J Clin Microbiol 31:2679-2682, 1993

17. Eyster ME, Fried MW, Di Bisceglie AM, Goedert JJ, for the Multicenter Hemophilia Cohort Study. Increasing hepatitis C virus RNA levels in hemophiliacs: Relationship to human immunodeficiency virus infection and liver disease. Blood 84:1020-1023, 1994

18. Rumi GM, Colombo M, Gringeri A, Mannucci PM: High prevalence of antibody to hepatitis $C$ virus in multitransfused hemophiliacs with normal transaminase levels. Ann Intern Med 112:379-380, 1990

19. Cheung RC, Chan RT, Lok ASF: Longitudinal study of hepatitis C viremia in chronic hepatitis C. J Med Virol 41:338-342, 1993

20. Gordon SC, Kodali VP, Silverman AL, Dmuchowski CF, Urdea MS, Chan CS, Wilber JC: Levels of hepatitis $\mathrm{C}$ virus RNA and liver histology in chronic type $\mathrm{C}$ hepatitis. Am J Gastroenterol 89:1458-1461, 1994

21. Hagiwara $H$, Hayashi $N$, Naito E, Kasahara A, Fusamoto $H$, Kamada T: Quantitation of hepatitis C virus RNA in serum of asymptomatic blood donors and patients with type $\mathrm{C}$ chronic liver disease. Hepatology 17:545-550, 1993

22. Lok ASF, Cheung R, Liu V: Hepatitis $C$ viremia in patients with Hepatitis $C$ virus infection. Hepatology 15:1007-1012, 1992

23. Gocke DJ, Greenberg HB, Karvey NB: Correlation of Australia antigen with posttransfusion hepatitis. JAMA 212:877-879, 1970

24. Public health service inter-agency guidelines for screening donors of blood, plasma, organs, tissues, and semen for evidence of hepatitis B and C. MMWR 40:1-17, 1991

25. Centers for Disease Control: Perspectives in disease preven- 
tion and health prevention: Safety of therapeutic products used for hemophilia patients. MMWR 37:441-450, 1988

26. Menitove JE: Current risk of transfusion-associated human immunodeficiency virus infection. Arch Pathol Lab Med 114:330-334, 1990

27. Julius C, Westphal RG: The safety of blood components and derivatives. Hematol Oncol Clin North Am 6:1057-1077, 1992

28. Colombo M, Mannucci PM, Carnelli V, Savidge GF, Gazengel C, Schimpf K: Transmission of non-A, non-B hepatitis by heat treated factor VIII concentrate. Lancet 2:1-4, 1985

29. Mannucci $P M$, Colombo $M$, Rodeghiero $F$ : Non- $A$, non- $B$ hepatitis after factor VIII concentrate treated by heating and chloroform. Lancet 2:1013, 1985

30. Alter HJ, Purcell RH, Shih J, Melpolder JC, Houghton M, Choo G-L, Kuo G: Detection of antibody to hepatitis C virus in prospectively followed transfusion recipients with acute and chronic non-A, non-B hepatitis. N Engl J Med 321:1494-1500, 1989

31. Marcellin P, Martinot-Peignoux M, Alida E, Branger M, Courtois F, Level R, Erlinger S, Benhamou JP: Hepatitis $C$ virus (HCV) viremia in human immunodeficiency virus seronegative and seropositive patients with indeterminate HCV recombinant immunoblot assay. J Infect Dis 170:433-435, 1994

32. Ragni MV, Ndimbie OK, Rice EO, Bontempo FA, Nedjar S: The presence of hepatitis $C$ virus (HCV) antibody in human immunodeficiency virus-positive hemophilic men undergoing HCV "seroreversion" Blood 82:1010-1015, 1983
33. Lok ASF, Chien D, Choo QL, Chan T-M, Chiu EKW, Cheng IKP, Houghton M, Kuo G: Antibody response to core, envelope and nonstructural hepatitis $C$ virus antigens: comparison of immunocompetent and immunosuppressed patients. Hepatology 18:497-502, 1993

34. Naito M. Hayashi N, Hagiwara $H$, Hiramatsu N, Kasahara A, Fusamoto $H$, Kamada T: Serum hepatitis $C$ virus RNA quantity and histological features of hepatitis $C$ virus carriers with persistently normal ALT levels. Hepatology 19:871-875, 1994

35. Alberti A, Chemello L, Cavalletto D, Tagger A, Dal Canton A, Bizzaro N, Tagariello G, Ruol A: Antibody to hepatitis C virus and liver disease in volunteer blood donors. Ann Intern Med 114:1010-1012, 1991

36. Esteban JI, Lopez-Talavera JC, Genesca J, Madoz P, Viladomiu L, Muniz E, Martin-Vega $C$, Rossel M, Allende $H$, Vidal $X$, Gonzalez A, Hernandez JM, Esteban R, Guardia J: High rate of infectivity and liver disease in blood donors with antibodies to hepatitis C virus. Ann Intern Med 115:443-449, 1991

37. Chazouilleres O, Kim M, Combs C, Ferrell L, Bacchetti P, Ascher NL, Roberts JP, Ascher NL, Neuwald P, Wilber J, Urdea M, Quan S, Sanchez-Pescador R, Wright TL: Quantitation of hepatitis $C$ virus RNA in liver transplant recipients. Gastroenterology 106:994-999, 1994

38. Brillanti S, Foli M, Gaiani S, Masci C, Miglioli M, Barbara L: Persistent hepatitis $C$ viremia without liver disease. Lancet; 341:464-465, 1993 